\title{
パーキンソン病における上肢運動機能障害の定量化 一反応運動と視標追跡運動時の有効パラメーターの検討一
}

\author{
中西亮二*1 村山伸樹*2 奥村チカ子*3 \\ 本木実*2 小林達矢 ${ }^{* 2}$
}

\section{Quantitative Analysis of Voluntary Movement Disorders in the Upper Limbs of Patients with Parkinson's Disease-Distinguishing Parameters in Reaction Movement and Visual Tracking Motion-}

\author{
Ryoji Nakanishi, ${ }^{* 1}$ Nobuki Murayama, ${ }^{* 2}$ Chikako Okumura, ${ }^{* 3}$ \\ Minoru Motoki, ${ }^{* 2}$ Tatuya Kobayashi ${ }^{* 2}$
}

\begin{abstract}
A quantitative analysis system for the functions of voluntary movements in the upper limbs was developed to identify parameters for distinguishing the movement functions of normal subjects and patients with Parkinson's disease. This system consisted of a personal computer and a digitizer tablet, to test a reaction movement task and a repetitive straight line motion task with visual tracking. Analysis of the reaction movement task showed that execution time was longer in patients with Parkinson's disease than that in normal subjects. The deviation component of the repetitive straight line motion task, which is the error in the vertical orientation from the trajectory of the target, was greater in the patients than in the normal subjects. Whereas, the delay component of the repetitive straight line motion task, which is the error in time from the trajectory of the target, was no difference between the two groups. Patients with Parkinson's disease were unable to modify their movement velocity to adapt to a visual tracking task with variable speeds, and also had difficulty in the tracking task in the horizontal orientation, but not in the vertical orientation. (Jpn J Rehabil Med 1999; 36 : 49-58)

要 旨：パーソナルコンピュータとデジタイザを組み合わせたシステムで反応運動および視 標追跡法による反復直線運動という 2 つ課題を用いてパーキンソン病患者（PD）の上肢運 動機能を評価した。その結果，反応運動では，PD 患者は健常老人に比べて移動時間が有意に 延長していた，反復直線運動では，視標に対しての時間的誤差である「遅れ成分」ょりも視標 の軌跡と垂直方向の誤差である「ずれ成分」に大きな特徴が示された．PD 患者は，一定の速 度で追跡する定速運動課題よりも運動時に速度が変化する変速運動課題の方が運動異常が出現 した。また，緹方向よりも横方向の反復運動の方が運動が困難であった。（リハ医学 1998 ; $35: 49-58)$
\end{abstract}

Key words : パーキンソン病 (Parkinson's disease), デジタイザ (digitizer), 反応運動 (reaction movement)，視標追跡法 (visual tracking method)，直線反復運 動（repetitive straight line motion）

1998 年 2 月 23 日受付, 1998 年 10 月 19 日受理

${ }^{* 1}$ 熊本機能病院リハビリテーション部/テ 860-0084 熊本市山室 6-8-1

Department of Rehabilitation Medicine, Kumamoto Kino Hospital

*2 熊本大学工学部電気システム工学科/ $7860-8555$ 熊本市黒髪 2-39-1

Department of Electrical \& Computer Engineering, Kumamoto University

*3 沖縄りハビリテーション学院作業療法科/T 901-1301 沖縄県良那原町字板良敷 1380-1

Department of Occupational Therapy, Okinawa College of Rehabilitation 
はじめに

パーキンソン病（PD）は，無動・臭動1,14,16,18,19)， 振戦6,17,19), 筋固縮6,17,19), 姿勢反射障害等を主徵とす る慢性進行性の変性疾患である。臨床的な評価には, 症状の重症度や日常生活障害度を指標とした Yahr の 重症度分類や Rating scale が用いられる。 上肢の機 能障害の評価法としては, タッピング試験やカウンタ 一押し, 回内回外試験など半定量的な方法もある。し かし, 臨床症状の主体である無動, 固縮, 振戦の評価 は, 検者の主観的な判断に寄らざる得ないのが実情で ある.このため, 病気の重症度判定やリハビリテーシ ヨンの効果および薬による病状改善などの客観的評価 が困難であり，また医師によって診断結果が違うなど の問題があった.

近年, いくつかの定量的な評価システムの開発や研 究がなされてきている 装置もまた, その複雑さや高価さに加え患者にとって 検查の負担が大きい等さまざまな問題点を抱えてお り，さらには上に述べたように PD の病態の多様性の ために有効なシステムの開発までは至っていない.

本研究の目的は，このような問題点をできるだけ考 慮した PD 患者に対するコンパクトな定量的診断シス テムを構築することである. 今回は, 基礎的研究とし てパーソナルコンピュータと液晶デジタイザを用いて システムを構築し， 2 種類の運動課題に対する有効な パラメータの検討を行った。
方

法

\section{1. 対 象}

対象は, 健常者の $20 \sim 49$ 歳 $(32.7 \pm 8.86$ 歳, 平均 值 $\pm \mathrm{SD})$ の年齢層を健常群 I として 29 例， 50 〜 76 歳 （63.5 土8.50 歳）の年齢層を健常群 II として 25 例と, 臨床的にPD と診断された $52 \sim 79$ 歳 $(64.4 \pm 9.20$ 歳）の患者 25 例（男性 13 例，女性 12 例）である. 罹病期間は $1 \sim 12$ 年. (平均 $5.6 \pm 3.5$ 年), 当院通院期 間は $1 \sim 9$ 年（平均 $3.3 \pm 2.7$ 年）であった. 全ての症 例が 2 剂以上の抗パーキンソン薬を 1 日 2 回以上に分 けて服用中であり, 検査施行時の Yahr の重症度分類 は, stage II : 10 例, stage III : 14 例, stage IV : 1 例であった。また, 生活機能障害度では, (I) 度 : 10 例, (II) 度：15例であった. 上肢の疾患度の左右差に ついては, 差が見られない患者が 25 例中 17 例, 右優 位が 6 例, 左優位者が 2 例であった. On-off 現象や dyskinesia が明らかな例, 痴呆やうつ状態の認めら れる例, その他検查が全て完結できなかった例は除外 してある。また，これらの患者については，脳血管障 害やその他の原因によるパーキンソン症候群は含ま ず，視覚障害をもたないことを確認しており，実験を 行う際には, あらかじめ実験の内容を患者に知らせて 同意を得ている。

\section{2. 測定方法}

システムは, パーソナルコンピュータ（NEC PC$9801 \mathrm{RX})$ とモノクロ液晶型ディスプレイ付きのデジ タイザ（ワコム HD-640 A）によって構成されている (Fig. 1).デジタイザは, Fig. 1に示すようにディス プレイ上のターゲット（約 $1 \mathrm{~cm}$ 大の星）が被験者に
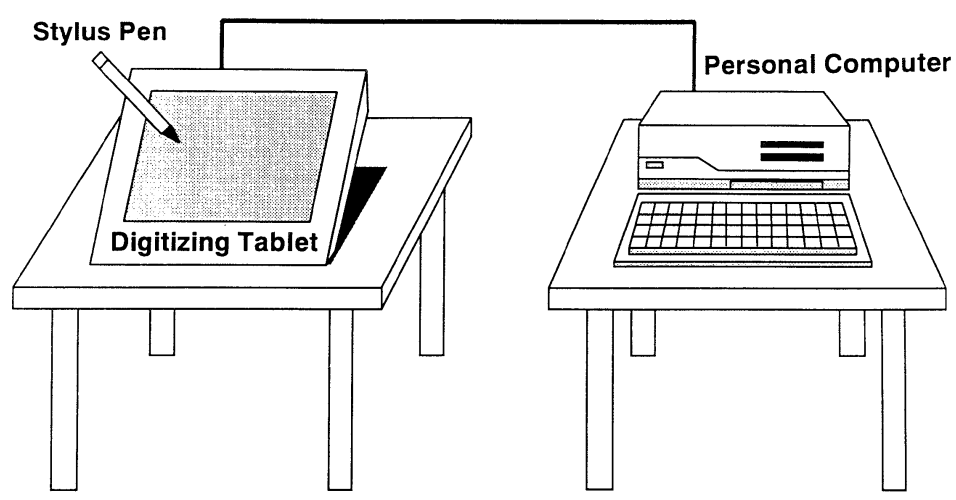

Fig. 1 Diagram of measuring system for voluntary movements in the upper limb. 
見えやすいように約 50 度傾けて設置した。被験者は デジタイザの前に座り, 器具に上肢が触れないように してスタイラスペン（重量：約 $9 \mathrm{~g}$ ）を持ち，ディス プレイ上を動くターゲットをペンで追跡する。このペ ンの位置（精度 $0.05 \mathrm{~mm}$ ）をコンピュータにデータ として取り込む。なお，PD 患者の検査を施行するに あたって, 定期の服薬時間带の直前や直後は避けた が, 午前, 午後および服薬からの時間というような規

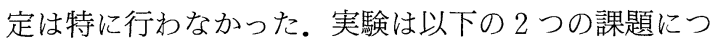
いて行い, 有効パラメータの抽出を試みた。

\section{課題 1 : 反応運動}

被験者は, 表示された星の中心をスタイラスペンで 指し，星を注視しながら待機する．実験者が「始めま す」と被験者に声をかけ，その 3 5 秒後にブザー音

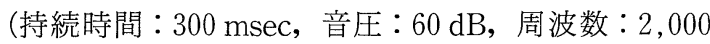
$\mathrm{Hz}$ ）が鳴ると同時に星が消え，かつ星から右側 15 $\mathrm{cm}$ 離れた画面上に垂直線が現れる。つまり，被験者 は聴覚 (ブザー音) と視覚（星が消える）の両感覚で 動作のトリガー点を得ることになる。この際に被験者 は，できるだけ早く反応し，垂直線を越える位置まで スタイラスペンを移動させる、本課題を利き手および 非利き手それぞれ 3 回行い，これを 1 試行として合計 2 試行行った。データの解析には 2 試行目のデー夕を 用いた (Fig. 2).

反応運動に要する時間について本実験では次の 2 種 類に分類した。すなわち，ブザー音の発生と同時に星 が消えてからスタイラスペンの先が動きだすまでの動 作開始時間，ここでは星の中心から $1 \mathrm{~cm}$ の正方形の

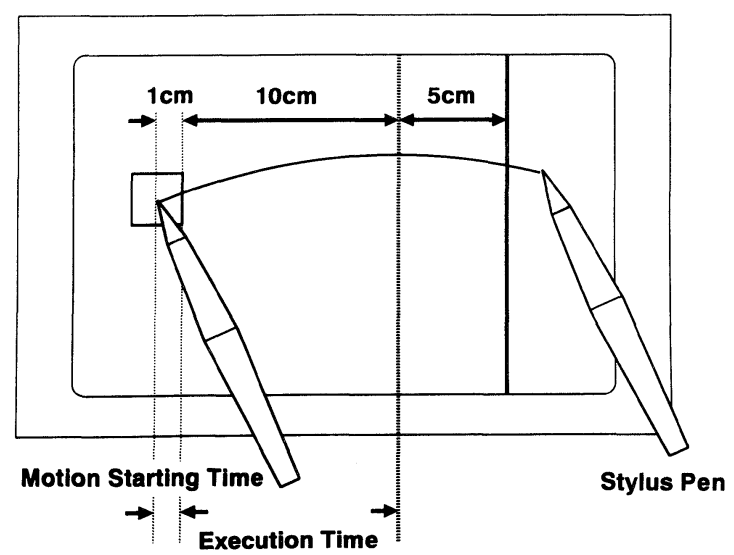

Fig. 2 Diagram of measurement of the reaction time and the movement time.
範囲を抜け出すまでの時間として計測したＰD 患者 では常に静止振戦があり，1点に静止することが困難 であることが知られている。このため予備実験とし て, 今回の実験に参加してもらう PD 患者にデジタイ ザ上の星の中心でスタイラスペンを持って 10 秒間静 止してもらい，この間のペンの移動範囲を計測したと ころ半径 $4 \mathrm{~mm}$ 以下であることがわかった。これを基 に動作開始時間を $1 \mathrm{~cm}$ の正方形の範囲を抜け出すま での時間することによって本当に動きだそうとしてぺ ンを動かす動作と静止振戦によるペンの動作とを区別 するようにした。もう1つは，動きだしてから右側に $10 \mathrm{~cm}$ 離れた位置を通過するまでの遂行時間である. これは星の中心から $15 \mathrm{~cm}$ の距離に表示してある垂 直線の手前でペンを止めたり，ペンのスピードを緩め る被験者がいたためである。時間の計測にはパーソナ ルコンピュータの内部タイマーを用いており, 測定の 精度は $1 \mathrm{msec}$ である。

各被験者の 2 試行目のデータの動作開始時間および 遂行時間についての平均值をその被験者の動作開始時 間および遂行時間とした。

\section{課題 $2:$ 直線反復運動}

まず，パーソナルコンピュータからの命令によりデ イスプレイ中央に追いかけるべきターゲットの星（約 $1 \mathrm{~cm}$ ）が表示される．被験者は，このターゲットの 中心をスタイラスペンで指し，ターゲットを注視しな がら待機する．実験者の合図から５秒後にターゲット がディスプレイ上で往復運動を始める。被験者は，こ のターゲットからできるだけ離れないようにしてペン で追跡する。この際に被験者にはターゲットからずれ たり，遅れたり，行き過ぎたりしないようにあらかじ め指示しておく．さらにターゲットの移動範囲の両端 に線を表示して移動範囲が被験者にわかるようにし た。本課題も上に述べた反応運動課題と同様に利き手 および非利き手で行った。その理由は健常者群では日 常的にペン等を使用している利き手と使用していない 非利き手で運動課題の違いによっては差が生じるので はないかと思われたからである。

また PD 患者の特徵として, リズムが不規則に変化 するような運動に困難さを伴うことが知られているの で，ここでは以下の 2 つの実験条件下で視標追跡運動 の解析を行った。

・条件 1：ターゲットの速さ $6 \mathrm{~cm} / \mathrm{sec}$ 一定

・条件 2 : ターゲットの速さが $3 \sim 6 \mathrm{~cm} / \mathrm{sec}$ の範 
囲でランダムに変化

また，往復運動の方向と範囲は，

・横方向 $16 \mathrm{~cm}$

・縦方向 $12 \mathrm{~cm}$

とし，それぞれの方向について各条件のもとで実験を 行った。すなわち,

・実験 1 : 横方向で速度一定

・実験 2 : 横方向で速度ランダム

- 実験 $3:$ 縱方向で速度一定

・実験 $4:$ 縦方向で速度ランダム

の 4 種類の実験を行い, Student's $t$-test を用いて有 効パラメータの検討を行った.

デジタイザの精度は $x$ および $y$ 成分について 0.05 $\mathrm{mm}$ ，データのサンプリング時間は $25 \mathrm{msec，データ}$ のポイント数は 1,024 ポイント, 取り込み時間は 25.6 秒間であった。

\section{結果}

\section{1. 反応運動}

健常群およびPD 患者の動作開始時間を Fig. 3 A に示す. 健常群 I では $232 \pm 43.1 \mathrm{msec}$ (平均值士標 準偏差), 健常群 II では $303 \pm 128.7 \mathrm{msec}$ となり, 平 均值もばらつきも健常群 Iに比べて大きくなった. $\mathrm{PD}$ 患者では， $348 \pm 108.0 \mathrm{msec}$ と同年代の健常老人 よりもやや遅延の傾向を示した. 各健常群および PD 患者群の間で有意差検定を行った結果, 健常群 I と健 常群 II との間には危険率 $p<0.01$ で有意差があり,
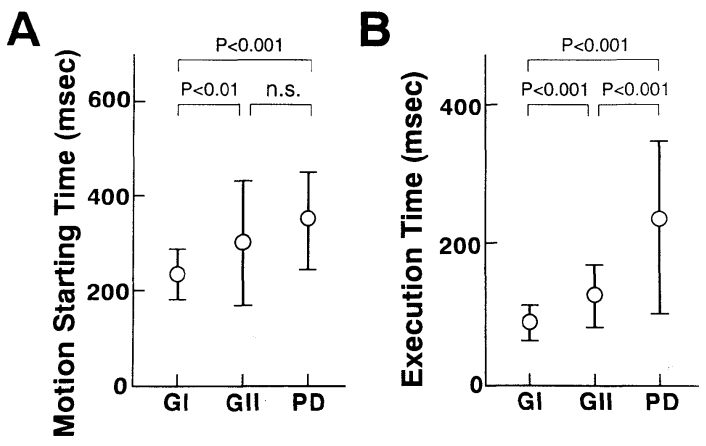

Fig. 3 Reaction movement in young and elder normal subject groups, and Parkinson's disease patient group.

(A) motion starting time, (B) execution time. GI, group I (young normal subjects); GII, group II (elder normal subjects); PD, Parkinson's disease patient group.
健常群 I と PD 患者との間には危険率 $p<0.001$ で高 度の有意差を認めた。しかしながら, 健常群 II と PD 患者の間には有意差は認められなかった（ $p>0.05 ）$. このことは, 健常者でも加齢に伴い動作開始時間が延 長することを示唆している.

一方, Fig. 3 B は, 健常群抢よび PD 患者の遂行時 間を示している.健常群 I では $87 \pm 20.5 \mathrm{msec}$ (平均 值士標準偏差), 健常群 II では $120 \pm 43.5 \mathrm{msec}, \mathrm{PD}$ 患者では $236 \pm 133.5 \mathrm{msec}$ となり, PD 患者の平均值 は健常群 I や健常群 II に比較して大きい值を示した。 各健常群および PD 患者群の間で有意差検定を行った 結果, 健常群 I と健常群 II および健常群 I と PD 患者 との間には危険率 $p<0.001$ で高度の有意差を認めた。 さらに，健常群 II と PD 患者の間にも高度の有意差 を認めた $(p<0.001)$.

以上の結果から, 健常群, 特に健常老人と PD 患者 とを識別するのに遂行時間が有効なパラメータである ことがわかった。

\section{2. 直線往復運動}

Fig. 4 A およびFig. 4 B は，それぞれ実験 1 にお ける健常者（若者）および PD 患者（重症）の入力波 形の $x$ 成分および $y$ 成分を時系列で示している. 破 線はターゲットの軌跡を，実線は被験者の筆跡を表わ している.

$x$ 成分の例において, 健常者（若者）では破線と実 線はあまりずれていないが，PD 患者（重症）では大 きくずれている。このずれはターゲットからの「遅れ 成分」を示していることになる。そこで軌跡の全区間 について，その遅れを加算した值として遅れの和を計 算した。また，遅れのばらつきを見るために遅れの標 準偏差を求めた。

さらに，PD 患者では一定の方向や速度でない夕ー ゲットの動きに対して, その追跡が困難と思われるこ とから, ターン時や速度変化時についての遅れ成分に ついても計測を行った. ターン時については, ターン してから 1 秒間の遅れの和を計算した。一方, 速度変 化時については, 速度が変化してから 0.5 秒間の遅れ について計算を行った。 以上をまとめて, ターゲット が一定の速度で動くような実験 1 （横方向）抢よび実 験 3 （縦方向）では，（1）全体の遅れの和，（2）遅 れの和の標準偏差, および (3) ターン時 1 秒間の遅 れの和について検討した。また，ターゲットの速度が 途中で变化するような実験 2 （横方向）および実験 


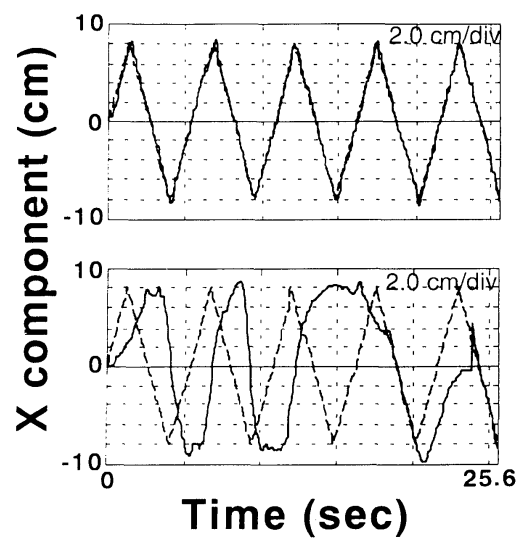

(A)

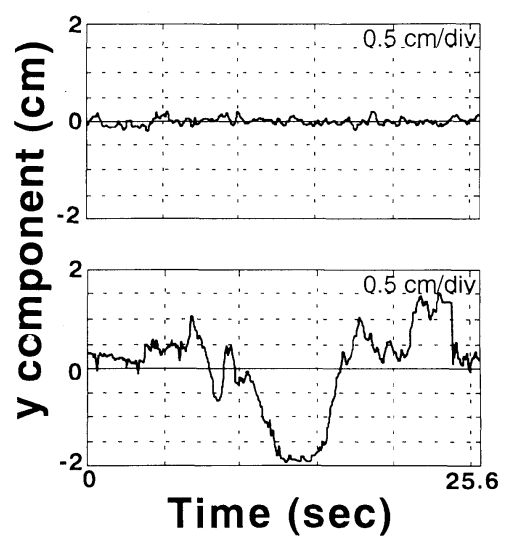

(B)

Fig. 4 An example of the input of manual tracking of visual target in experiment $\mathrm{I}$.

(A) $x$ component, (B) y component. Upper: a normal subject, Lower: a patient with PD. Solid line, locus of a stylus pen; Dash line, locus of a target.

4 (縦方向) の場合には, 上に述べた 3 個のパラメー 夕に（4）速度変化時 0.5 秒間の遅れの和のパラメー 夕を加えて 4 個のパラメータについて検討した.

一方, 実験 1 （横方向）におけるターゲットの軌跡 は $y=0$ の直線を示すことになるが, 被験者の筆跡は 上下に震えるため $y$ 軸方向にペンの軌跡が現われる. ペンの軌跡と $y=0$ の直線との差の絶対值を「ずれ成 分」とした。この「ずれ成分」に関して実験 1 および 実験 3 については，（5）全体のずれの和，（6）ずれ の和の標準偏差, および ( 7 ) ターン時 1 秒間のずれ の和について検討した。実験 2 およ゙実験 4 について は, (8) 速度変化時 0.5 秒間のずれの和を加えて 4 個のパラメータについて検討した。すなわち, 実験 1 および実験 3 については 6 個の, 実験 2 および実験 4 については 8 個のパラメータについての有効性を Student's $t$-test を用いて検討した.

Table 1 および Table 2 は, 実験 1〜4の各パラメー 夕について, それぞれ健常群 I と健常群 II 間, およ び健常群 II と PD 患者群間の有意差結果をまとめた ものである、上段が利き手の, 下段が非利き手の結果 を示している.

Table 1 からわかることは, 健常群 I と健常群 II の 各パラメータで高度の有意差 $(p<0.001)$ を示したも のが，実験 3 のずれの標準偏差を除いて全て遅れ成分 を示すパラメータであったということである。これ は，老人は若者に比べターゲットを追跡するのが遅れ る傾向があることを意味しており，加齢に伴い「運動
の遅れ」が顕著になったことがわかるまた，各グル ープに扔ける利き手と非利き手との間の有意差は認め られなかった $(p>0.05)$. 一方, Table 2 を見ると, 健常群 II と PD 患者の各パラメー夕間で利き手およ び非利き手の両側肢とも高度の有意差 $(p<0.001)$ を 示したものは, 遅れ成分で 4 個（実験 2 および実験 $3)$, ずれ成分で 10 個（実験 2 , 実験 3 および実験 4) であった。これは，PD患者は健常老人に比べて遅れ の成分よりもずれの成分に大きく特徴が表れており， $\mathrm{PD}$ 患者が同年齢の健常老人よりも振戦や固縮という PD 患者特有の症状が顕著に悪化していることを示唆 している.

\section{3. 各パラメータによる PD 患者陽性検査}

次に, 各 PD 患者が上に述べたパラメータの中のど のパラメータで PD 陽性と鑑別されるか調べた。鑑別 方法は, 健常者の各パラメータの值が正規分布してい ると仮定して各パラメータの平均值十標準偏差 $\times 1.5$ 以内 $(93.3 \%$ が含まれる) を正常值とし, この判定値 以上をとるような被験者は PD 陽性と診断することに した．ここでは, PD 患者と同年代に当たる健常群 II の利き手に扔ける各パラメー夕值を判定值として用 い，被験者に対して利き手および非利き手のいずれか の各パラメータ值が判定值以上であった場合に PD 陽 性とみなした。

PD 患者についての評価結果を Table 3 に示す. PD 患者は 25 例中, 全例が PD 陽性と鑑別されている. 実験別に有効な判定パラメー夕数を調べると, 実験 1 


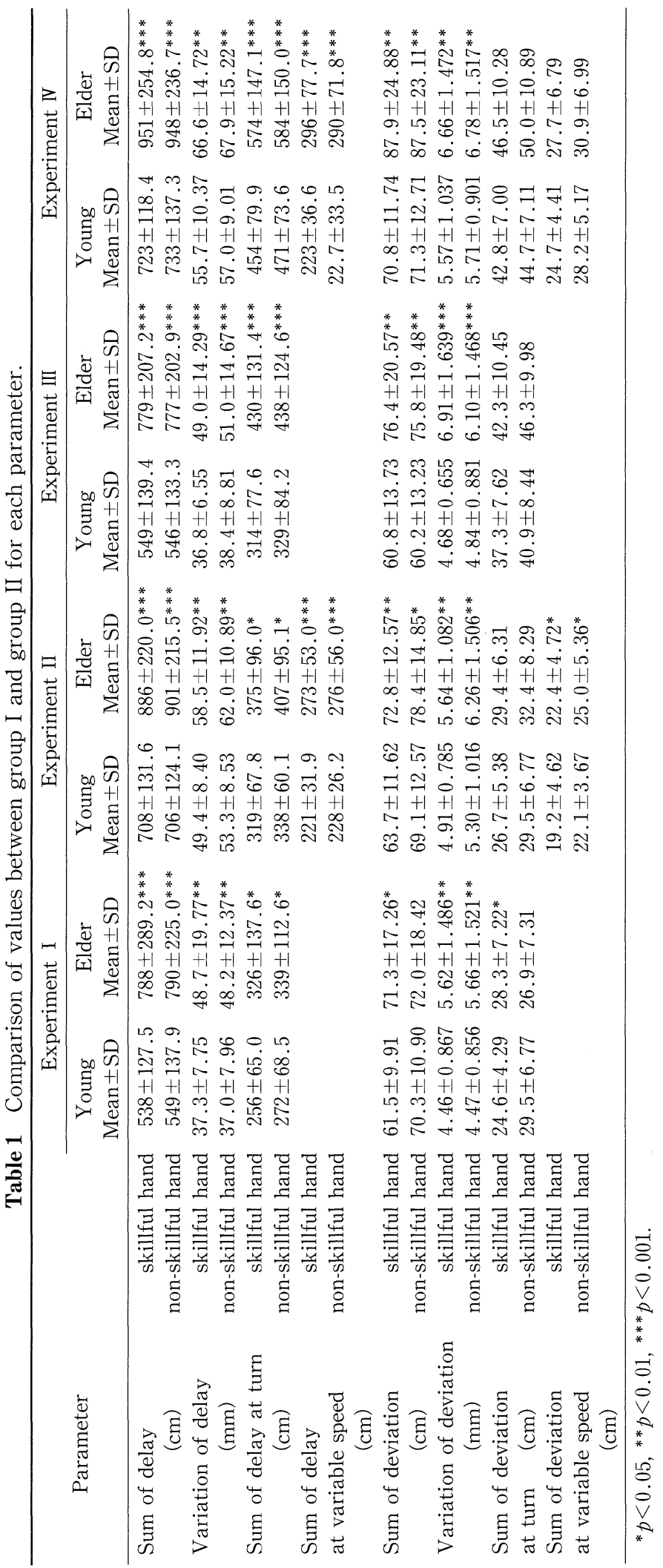




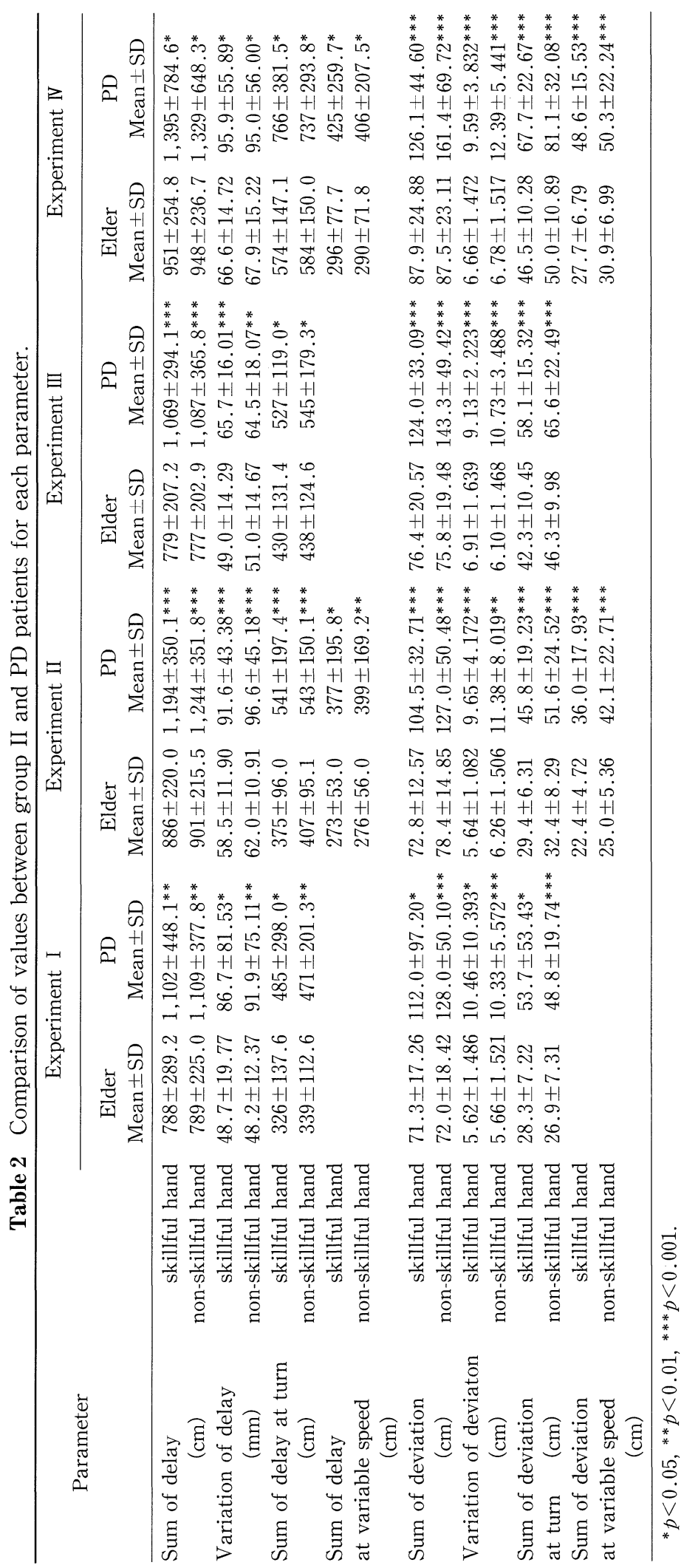




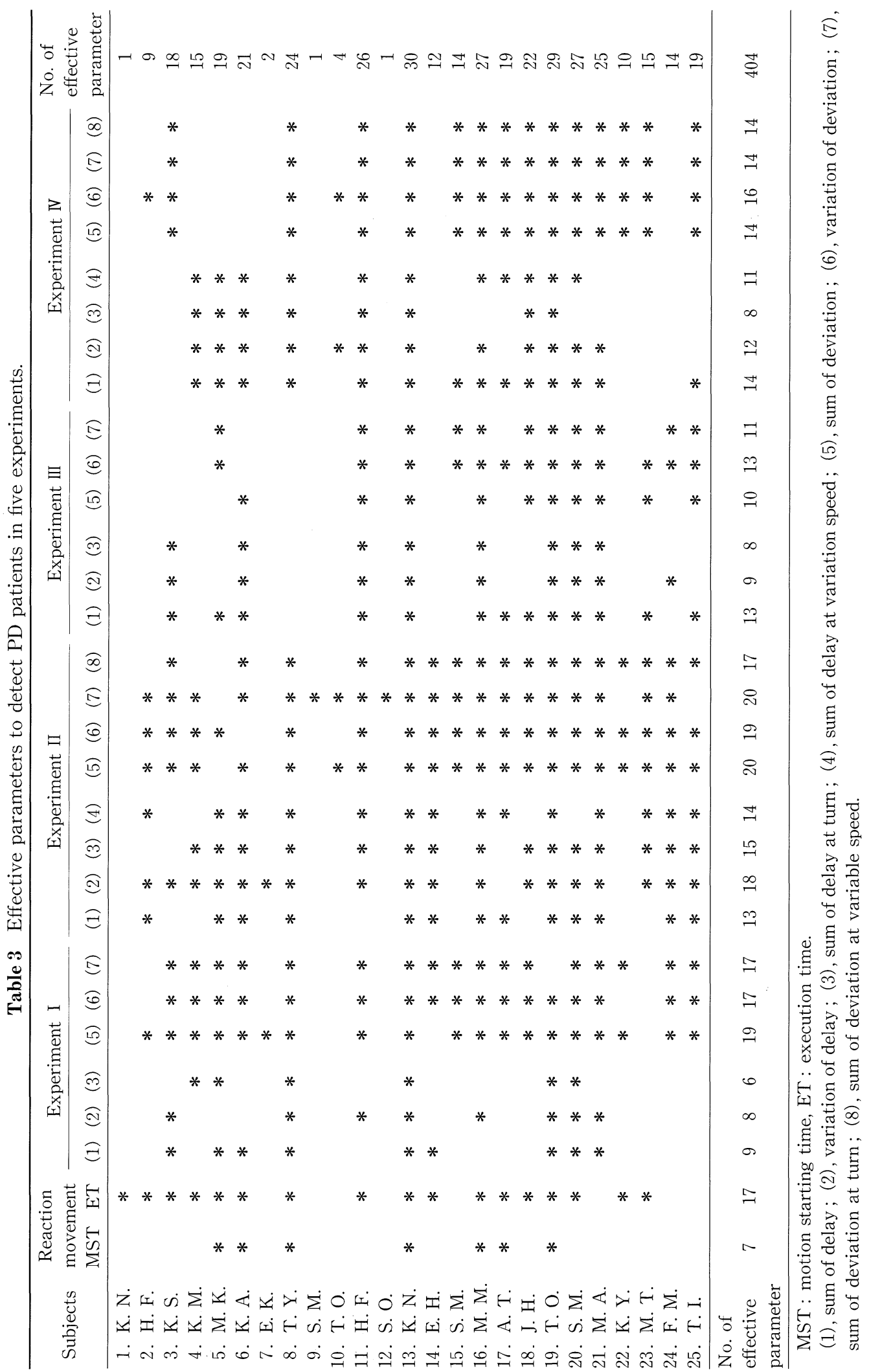


では 76 個，実験 2 では 136 個，実験 3 では 64 個，実 験 4 では 104 個であった。このことは, 実験 2 の横方 向で速度がランダムに変化する実験条件が最もよく PD 患者を鑑別していることになる．また，最右端は 各被験者を判別するのに有効なパラメータの数を表わ している.これを見ると, 大部分の患者は 10 個以上 のパラメータで陽性と鑑別されているが，4個のパラ メータで判別された者 1 例, 2 個のパラメータで判別 された者 1 例および 1 個のパラメータで判別された者 3 例であった. これらの有効名パラメータのうち 1 個 を除いて実験 2 および実験 4 のパラメータであった. このことからも, 実験 2 および実験 4 のようにターゲ ットの速度がランダムに変化する方が, 一定の速度で 移動する実験よりも PD 患者を判別するのに適してい ることが示唆された。

一方，健常群 II で PD 患者と鑑別された例は 25 例 中 9 例で, 9 例の被験者はいずれも各実験条件課題の 中の 2,3 個のパラメータで陽性と診断された.

\section{考察}

本実験における反応運動に関して, PD患者は健常 老人と比べて動作開始時間よりも遂行時間に遅延異常 が多く見られた，本実験の反応運動課題は，標的への 正確な移動を課すような Choice Reaction Taskや Simple Reaction Task というよりも，もっと簡単な Non-aimed Reaction Task ${ }^{16)}$ に該当する.このため, 中枢神経系における運動計画や運動準備に関する時間 を含んでいる動作開始時間については, PD 患者と健 常群 II との間には有意差が生じなかったものと思わ れる. 一方, 遂行時間についてはPD 患者群の移動速 度は平均で約 $0.42 \mathrm{~m} / \mathrm{sec}$, 健常群 II では $0.83 \mathrm{~m} / \mathrm{sec}$ と PD 患者の移動速度が非常に減速していた。これは 遂行時間が PD 患者の症状の 1 つである動作緩徐を表 わしているものと推定される.この結果は, Berardelli ら ${ }^{1)}$, Evarts $^{2)}$, Ghika ら², Sheridan ${ }^{16)}$ が行っ た研究結果と同様であった。

直線往復運動における「遅れ成分」と「ずれ成分」 に関して, 健常群 I と健常群 II を比較した時, 遅れ 成分にのみ有意差が示された。これは，一般的に老人 は若者に比べてターゲットを追跡するのが遅れる傾向 があることを意味しておう，年齢の増加に伴って遅れ が生じるということを意味している. 一方, PD 患者 群と健常群 II を比較すると,「遅れ成分」のパラメー
タよりも「ずれの成分」のそれに高度の有意差を持つ ものが多かった。これは, PD 患者の特徵である振戦 および動作緩徐が健常老人よりも顕著に現われること を示唆しているものと思われる。

各パラメー夕を用いて, 個々の PD 患者の陽性検查 行うと, Table 3 でわかるように実験 2 および実験 4 のように追跡中に視標の速度がランダムに変化する条 件の方が PD 患者を識別するのに有効なことがわかっ た.このことは, PD 患者が運動の途中でのリズム変 化に追随するのが困難であることを示している.さら に, 運動方向を見ると縦方向よりも横方向の運動の方 が PD 患者を識別するのに有効であることが示され た。これは, 以前に報告されたように脊髄小脳変性症 では横方向よりも縦方向の視標追跡運動により異常が

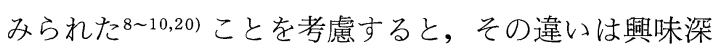
い.しかしながら，今回の実験では縦方向が $12 \mathrm{~cm}$, 横方向が $16 \mathrm{~cm}$ であったため, PD 患者では横方向に 視標追跡を行う際に眼球運動に制限があった可能性も 否定できない。この点については,さらに実験を行な いたい.

最後に, 今回の実験結果から, 実験 2(横方向, 速 度ランダム）の 8 個のパラメータと反応運動における 反応時間および遂行時間を用いて，ニューラルネット ワークを組み込んだ自動診断支援システムを構築した w.

稿を終えるにあたり, 慇切なご指導とご鞭趛を戴いた熊 本機能病院院長米満弘之先生に深謝致します。

\section{文献}

1) Berardelli A, Accornero N, Argenta M, Meco G, Manfredi M: Fast complex arm movements in Parkinson's disease. J Neurosurg Psychiatry 1986 ; 49: 1146-1149

2) Evarts EV, Teravainen H, Calne DB: Reaction time in Parkinson's disease. Brain 1981; 104: 167186

3) Ghika J, Wiegner AW, Fang JJ, Davies L, Young RR, Growdon JH : Portable system for quantifying motor abnormalities in Parkinson's disease. IEEE Trans Biomed Eng 1993; 40: 276-283

4) Hocherman S, Aharon-Peretz J : Two-dimensional tracing and tracking in patients with Parkison's disease. Neurology $1994 ; 44: 111-116$

5）石田 暉：上肢不随意運動の定量的評価法. リ八医学 $1984 ; 21: 247-254$

6) Marsden $\mathrm{CD}$ : The mysterious motor function of the basal ganglia: the Robert Wartenberg lecture. 
Neurology $1982 ; 32: 514-539$

7）松岡幸彦, 櫻井信夫, 古池保雄, 高橋 昭, 古河一憲, 久 野 皓: 上肢運動解析システムの開発. 厚生省特定疾 患一運動失調症研究報告書 $1988 ; 125-128$

8）村山伸樹, 島崎貴志, 奥村チカ子, 中西亮二：上肢運動 失調症に対する客観的評価法の検討 I . 自由描円運動 時の有効指標. 脳波と筋電図 $1993 ; 21: 245-253$

9）村山伸樹, 島崎貴志, 奥村チカ子, 中西亮二：上肢運動 失調症に対する客観的評価法の検討 II. 視標追跡運動 時の有効指標. 脳波と筋電図 $1993 ; 21$ : 254-262

10）村山伸樹, 奥村于カ子, 中西亮二, 本木 実, 小林達矢: ニューラルネットワークを用いた上肢運動失調症に対 する自動診断支援システムの開発一脊髄小脳変性症へ のアプローチ一. 脳波と筋電図 $1997 ; 25: 276-285$

11) 中西亮二, 山永裕明, 奥村于力子, 村山伸樹, 出田 透: 上肢運動失調の定量的解析. 臨床神経学 $1992 ; 32$ : 251-258

12）中村正俊, 西田茂人, 武藤祐二, 池田昭夫, 音成龍司, 柿 木隆介, 柴崎 浩: 2 次元画面視標追跡による手の随 意運動機能の記録処理法. 医用電子と生体工学 1990 ; $28: 9-17$

13）中村正俊, 杉剛 直, 柴崎 浩, 寺田清人: 視標追跡運 動機能のニューラルネットワークによる病態別特徴の 解析. 医用電子と生体工学 $1993 ; 31$ : 245-253
14) Sanes JN : Information processing deficits in Parkinson's disease during movement. Neuropsychology $1985 ; 23: 381-392$

15）千野直一, 石田 暉, 野田幸男, 富田 豊：上肢運動失 調の定量的評価一position と force の関係. 厚生省特 定疾患一運動失調症研究報告書 $1982 ； 132-141$

16) Sheridan MR, Flowers KA, Hurrell J : Programming and execution of movement in Parkinson's disease. Brain 1987; 110 : 1247-1271

17) Stern $Y$, Mayeux R, Rosen J, Ilson J : Perceptual motor dysfunction in Parkinson's disease : a deficit in sequential and predictive voluntary movement. J Neurol Neurosurg Psychiatry 1983 ; 46 : 145-151

18) Teasdale N, Phillips J, Stelmach GE: Temporal movement control in patients with Parkinson's disease. J Neurol Neurosurg Psychiatry 1990 ; 53 : 862-868

19) Warabi T, Yanagisawa $N$ : Changes in strategy of aiming-tasks in Parkinson's disease. Brain 1985; 111 : 497-505

20）吉澤 誠, 二坂広美, 竹田 宏, 大友 仁, 鴻巣 武, 佐 藤 元, 大坂和久: 人間オペレー夕の制御特性の異方 性と脳の両側性. 医用電子と生体工学 $1988 ； 26 ： 187-$ 195 